\begin{tabular}{lr}
\hline \multicolumn{1}{c}{ D Y N A M I C E C O N O M E T R I C } & M O D E L \\
DOI: http://dx.doi.org/10.12775/DEM.2016.007 & Vol. 16 (2016) 117-131 \\
\hline $\begin{array}{l}\text { Submitted November 30, 2016 } \\
\text { Accepted December 20, 2016 }\end{array}$ & ISSN (online) 2450-7067 \\
ISSN (print) 1234-3862
\end{tabular}

Krzysztof Kompa, Dorota Witkowska*

\title{
Performance of Pension Funds and Stable Growth Open Investment Funds During the Changes in the Polish Retirement System
}

\begin{abstract}
A bstract. The conditions of the pension funds (OFE) functioning were essentially changed in the years 2011-2014. The aim of the paper is to find out if these modifications influence the efficiency of the pension funds and to compare the performance of these funds to stable growth open investment funds (FIO). The analysis is provided for selected funds in the years 2009-2015. We conclude that in the examined period, OFE performed better than FIO, and the modifications of the rules for the pension funds caused the increase of risk and decrease of investment efficiency of these funds' portfolios.
\end{abstract}

K e y w o r d s: pension funds, stable growth open investment funds, investment efficiency, Sharpe model, CAPM, Sharpe, Treynor and Jensen ratios.

J E L Classification: G11; C12.

\section{Introduction}

The pension system in communist Poland was the defined benefit and pay-as-you-go (PAYG) scheme. However, the demographic changes, pension privileges concerning more and more occupational groups and economic sectors, together with the so-called early retirement regulations, which

\footnotetext{
* Correspondence to: Krzysztof Kompa, Warsaw University of Life Sciences - SGGW, Department of Econometrics and Statistics, 166 Nowoursynowska Street, 02-787 Warsaw, Poland, e-mail: Krzysztof_kompa@sggw.pl; Dorota Witkowska, University of Lodz, Department of Finance and Strategic Management, 22/26 Matejki Street, 90-237 Lodz, Poland, Dorota.witkowska@uni.lodz.pl

(C) 2016 Nicolaus Copernicus University. All rights reserved. http://www.dem.umk.pl/dem
} 
went into force in late 70 -ties ${ }^{1}$, caused the increase of the pension system costs. In 1981 the pension contribution was $25 \%$ of wages, in the years 1987-1989 it rose to 38\%, and obtained the level of $45 \%$ in 1990 (see (Wojciechowski 2011, Podstawka 2005, p. 259)).

The increasing deficit in the Polish pension system enforced its transformation, which took place in 1999. The new pension system replaced defined benefit scheme by defined contribution one, it enriched the PAYG system by the mandatory capital-funded pillar, and introduced voluntary plans. New regulations were also to abolish sectoral and occupational privileges and early retirement programs. The reformed retirement system has been consisted in three pillars - Social Insurance Institution (ZUS), open pension funds (OFE) and voluntary capital-funded system. The pension contribution (i.e. $19.52 \%$ of earnings) was divided between both mandatory pillars - ZUS $12.22 \%$ and OFE 7.3\%.

The first essential manipulation in the original pension reform was made in 2011 when the contribution to pension funds was diminished from $7.3 \%$ to $2.3 \%$. The second and the most drastic regulation, consisted in shifting $51.5 \%$ of the assets, held by the pension funds, to the Social Insurance Institution (including all debt securities issued and guaranteed by the State Treasury). Overhaul of the pension system also concerned changes in the OFEs' investment portfolio since private pension funds have no longer been allowed to invest in government bonds. These new law (from 2013) went into effect in February 2014. The third significant modification took place in 2014 and changed the character of pension funds which have been no longer obligatory. According to the new regulations, each employee has had four months every four years to decide whether 2.92 percent of their income goes to a chosen private fund or to ZUS. It means that after all mentioned above regulations the part of the pension contribution transferred to the pension funds decreased from $37.4 \%$ to $15 \%$ or even zero.

There have been numerous studies concerning the efficiency of mutual and pension funds operating in Poland. Mutual funds' performance is analyzed by Karpio and Żebrowska-Suchodolska (2010, 2011, 2012), Ostrowska (2003), Perez (2012), Witkowska (2009), Witkowska et al. (2009) and Zamojska (2012). Whereas evaluation of pension funds investment activity is made by Białek (2009), Chybalski (2006, 2009), Dybał (2008), Karpio and Żebrowska-Suchodolska (2014, 2016), Kompa and

\footnotetext{
${ }^{1}$ Early retirement regulations decreased the real pension age by several years since employees who fulfil certain conditions were allowed to obtain pension benefits earlier i.e. before statutory retirement age.
} 
Wiśniewski (2015), Kompa and Witkowska (2015, 2016), Marcinkiewicz (2009) and Witkowska, Kompa (2012). The mentioned research was provided for differently defined time spans, length of the samples, various frequency of measurement, taking into account bear and bull markets, and variety of efficiency measures. However, the investigation concerning the influence of political decisions to the performance of pension and investment funds market is rare. There is also lack of profound comparable research of the efficiency of pension and mutual funds.

This paper is to fulfill that gap in literature. The aim of our research is to find out if mentioned above changes of the OFEs' functioning influence the efficiency of the pension funds and to compare the performance of these funds to stable growth investment funds (FIO). The analysis is provided for selected funds applying statistical inference, Sharpe and capital assets pricing (CAPM) models and classical investment efficiency ratios.

\section{Data and Methods}

To answer the question about the consequences of manipulations in the pension system, the whole period of analysis, denoted by A, is divided into three pairs of sub-periods according to the moments when new regulations went into effect:

- B, decreasing of the contribution transferred to OFE,

- C, shifting of assets from OFE to ZUS and changes in the OFEs' portfolio composition,

$-\mathrm{D}$, waving the obligation of pension funds membership.

Empirical analysis of the investment efficiency is provided on the basis of daily observations from the years 2009-2015. The considered time span covers seven samples:

- A from 1.01.2009 to 31.12.2015 (84 months),

- B1 from 1.01.2009 to 30.04.2011, and B2 from 1.05.2011 to 31.08.2013 (28 months each sub-period),

- C1 from 1.04.2012 to 31.01.2014, and C2 from 1.02.2014 to 31.12.2015 (22 and 23 months respectively),

- D1 from 1.01.2013 to 30.06.2014, and D2 from 1.07.2014 to 31.12.2015 (18 months each).

In our research we use daily logarithmic rate of returns evaluated from:

- participation units of stable growth open investment funds and accounting units of pension funds, which are managed by the same six investment and pension funds companies, namely: Allianz, Aviva, Nationale 
Nederlanden, PEKAO, PKO and PZU Investment and Pension Funds Companies ${ }^{2}$,

- Warsaw Stock Exchange Index - WIG,

- Poland's Official Treasury Bonds Index - TBSP.Index, and

- Warsaw Interbank Offered Rate - WIBOR.

WIG, TBSP and WIBOR (being the interest rate of 3 months loans) are used as benchmarks ${ }^{3}$ in our analysis since they represent capital, treasury bond and money markets, respectively. WIG is treated as the market index whereas TBSP and WIBOR - as risk free instruments.

Analysis of returns and risk generated by the investment portfolios constructed by selected funds is conducted using statistical interference (assuming the significance level 0.05 ). We will verify ${ }^{4}$ the following null hypotheses concerning:

\begin{tabular}{lll}
\hline rates of return & risk & Sharpe model / CAPM \\
\hline$E\left(R_{\text {OFE }}\right)=0 ;$ & & $\beta=0 ; \alpha=0$ \\
$E\left(R_{F I O}\right)=0 ;$ & & \\
$E\left(R_{\text {benchmark }}\right)=0$ & $D^{2}\left(R_{\text {OFE }}\right)=D^{2}\left(R_{F I O}\right)$ & $\beta$ OFE $=\beta$ FIO \\
\hline$E\left(R_{\text {OFE }}\right)=E\left(R_{F I O}\right)$ & $D^{2}\left(R_{\text {before }}\right)=D^{2}\left(R_{\text {after }}\right)$ & $\beta_{\text {before }}=\beta_{\text {after }}$ \\
\hline$E\left(R_{\text {before }}\right)=E\left(R_{\text {after }}\right)$ & &
\end{tabular}

where, $E(R)$ - expected returns, $D^{2}(R)$ - variance of returns, $R_{\mathrm{OFE}}, \mathrm{R}_{\mathrm{FIO}}$ - returns from OFE and FIO respectively, $\beta, \alpha$-parameters of Sharpe model or CAPM, $R_{\text {before }}, R_{\text {after }}, \beta_{\text {before }}, \beta_{\text {after }}-$ returns from the portfolio and beta coefficients before and after the change went into effect, respectively.

The comparison of the funds' efficiency is provided applying Sharpe, Treynor and Jensen ratios which are evaluated for all considered pension and mutual funds in all analyzed time spans, and for differently defined risk free instruments.

\section{Rates of Return}

In the first step of our analysis we check out if daily rates of return are significantly positive or negative. It is visible (Table 1) that expected returns from all considered pension funds' investment are significantly positive in

\footnotetext{
${ }^{2}$ The selection of mentioned above Investment and Pension Funds Companies is connected with the investigations previously provided by the authors separately for pension funds and investment funds.

${ }^{3}$ It is worth mentioning that WIG and WIBOR are used to calculate benchmarks, which are used to evaluate pension funds efficiency (Dziennik Ustaw Rzeczypospolitej Polskiej 2014, poz. 753).

${ }^{4}$ Description of all applied tests is presented in (Tarczyński, Witkowska and Kompa, 2013, p. 18-19, 25, 72)
} 
the whole period of consideration (denoted by A), and for the periods B1 and $\mathrm{C} 1$, describing performance of pension funds before the essential changes of their functioning. It is also noticeable that in the periods $\mathrm{C} 2$ and D2, i.e. after the modifications went into effect, the average rates of return are negative, although the null hypothesis cannot be rejected for the significance level 0.05 .

Table 1. Test statistics verifying the hypothesis about expected returns from pension funds in considered periods $\mathrm{H}_{0}$ : $\mathrm{E}\left(\mathrm{R}_{\mathrm{OFE}}\right)=0$

\begin{tabular}{cccccccc}
\hline Period & A & B1 & B2 & C1 & C2 & D1 & D2 \\
\hline Number of observations & 1823 & 604 & 610 & 480 & 499 & 390 & 393 \\
Allianz & 1.9306 & $\mathbf{2 . 7 3 6 0}$ & 1.3129 & $\mathbf{2 . 4 9 1 1}$ & -0.1800 & 0.7590 & -0.3116 \\
Aviva & 1.7404 & $\mathbf{2 . 6 5 0 9}$ & 1.2352 & $\mathbf{2 . 2 9 7 4}$ & -0.2728 & 0.7827 & -0.4601 \\
Nationale Nederlanden & 1.7662 & $\mathbf{2 . 6 3 6 4}$ & 1.3028 & $\mathbf{2 . 4 4 3 8}$ & -0.3501 & 0.8735 & -0.5018 \\
PEKAO & 1.5230 & $\mathbf{2 . 7 9 9 7}$ & 1.0987 & $\mathbf{2 . 2 5 5 7}$ & -0.4316 & 0.7572 & -0.6005 \\
PKO & $\mathbf{2 . 0 5 4 0}$ & $\mathbf{2 . 9 1 0 2}$ & 1.4263 & $\mathbf{2 . 6 6 2 0}$ & -0.1030 & 0.9630 & -0.2776 \\
PZU & $\mathbf{1 . 7 0 4 3}$ & $\mathbf{2 . 5 4 1 3}$ & 1.0815 & $\mathbf{2 . 2 3 5 3}$ & -0.1397 & 0.8623 & -0.3361 \\
\hline
\end{tabular}

Note: Bold letters denote rejection of null hypothesis.

Table 2. Test statistics verifying the hypothesis about expected returns from stable growth investment funds in considered periods $\mathrm{H}_{0}$ : $\mathrm{E}\left(\mathrm{R}_{\mathrm{FIO}}\right)=0$

\begin{tabular}{cccccccc}
\hline Period & A & B1 & B2 & C1 & C2 & D1 & D2 \\
\hline Number of observations & 1823 & 604 & 610 & 480 & 499 & 390 & 393 \\
Allianz & 0.0849 & 0.5640 & -0.1806 & 0.1617 & -0.5957 & -0.2008 & -0.8648 \\
Aviva & 2.0625 & 1.9847 & 0.7763 & 1.8784 & 0.0660 & 1.0115 & -0.0550 \\
Nationale Nederlanden & 1.7755 & 1.8450 & 0.6528 & 1.6648 & 0.2879 & 0.6511 & -0.2487 \\
PEKAO & 0.3032 & 1.6871 & -1.0786 & 0.6526 & -0.3112 & 0.1099 & -0.5922 \\
PKO & 2.1753 & 1.8920 & 0.8929 & 1.8669 & 0.5899 & 0.9977 & 0.1458 \\
PZU & 1.1236 & 1.5555 & 0.3250 & 1.3278 & -0.6382 & 0.5266 & -0.6100 \\
\hline
\end{tabular}

Note: Bold letters denote rejection of null hypothesis.

Stable growth investment funds' performance (Table 2) seems to be worse than the pension funds since only Aviva, Nationale Nederlanden and PKO generated significantly positive returns in the periods A, B1 and C1. However, the comparison of returns, using Cochran-Cox test (Table 3), shows that differences between returns obtained by both types of funds are not significant, except PEKAO in B2 when OFE performed better than mutual fund.

Analyzing returns from the benchmarks (Table 4) one may notice that interest rate WIBOR generated positive returns in all periods, bond market performed well with significantly positive returns in all periods but D1 and D2, whereas expected returns from WIG do not significantly differ from zero, except the period B1. 
Table 3. Test statistics for comparison of expected returns $\mathrm{H}_{0}$ : $\mathrm{E}\left(\mathrm{R}_{\mathrm{OFE}}\right)=\mathrm{E}\left(\mathrm{R}_{\mathrm{FIO}}\right)$ and risk $\mathrm{H}_{0}: \mathrm{D}^{2}\left(\mathrm{R}_{\mathrm{OFE}}\right)=\mathrm{D}^{2}\left(\mathrm{R}_{\mathrm{FIO}}\right)$ for pension and investment funds

\begin{tabular}{cccccccc}
\hline Period & Hypotheses & Allianz & Aviva & NN & PEKAO & PKO & PZU \\
\hline A & Return & 1.1902 & -0.0116 & 0.1989 & 1.0688 & 0.2125 & 0.0000 \\
& Variance & 1.0935 & 1.1017 & 1.1702 & 1.0740 & 1.3329 & 1.5200 \\
B1 & Return & 0.8956 & -0.0783 & 0.1499 & 0.1975 & 0.5473 & -0.2761 \\
& Variance & 1.6486 & 1.4068 & 1.2048 & 1.4157 & 1.0283 & 1.9268 \\
B2 & Return & 0.8969 & 0.3501 & 0.3934 & 1.6668 & 0.3259 & 0.2907 \\
& Variance & 1.4784 & 1.0615 & 1.0968 & 1.3140 & 1.0511 & $\mathbf{2 . 0 0 0 0}$ \\
C1 & Return & 1.9833 & 0.2024 & 0.6182 & 0.8171 & 0.7680 & -0.2969 \\
& Variance & 1.1808 & 1.0581 & 1.2008 & 1.1005 & 1.2324 & $\mathbf{2 . 0 0 0 0}$ \\
C2 & Return & 0.2589 & -0.3431 & -0.4286 & -0.1533 & -0.2260 & 0.4545 \\
& Variance & $\mathbf{2 . 0 6 6 7}$ & $\mathbf{2 . 1 1 6 9}$ & $\mathbf{2 . 1 3 7 5}$ & $\mathbf{2 . 0 3 5 1}$ & $\mathbf{2 . 4 1 1 0}$ & 0.9857 \\
D1 & Return & 0.8041 & 0.0796 & 0.2887 & 0.5390 & 0.2098 & 0.0000 \\
& Variance & 1.6271 & 1.3958 & 1.4758 & 1.3195 & 1.7198 & 1.5306 \\
D2 & Return & 0.0885 & -0.2676 & -0.4538 & -0.2788 & -0.3561 & 0.2107 \\
& Variance & $\mathbf{2 . 0 1 3 4}$ & $\mathbf{2 . 1 9 9 1}$ & $\mathbf{2 . 1 1 5 7}$ & $\mathbf{2 . 0 9 4 4}$ & $\mathbf{2 . 3 6 1 6}$ & 1.0462 \\
\hline
\end{tabular}

Note: NN is an abbreviation of Nationale Nederlanden. Bold letters denote rejection of null hypothesis. Shadowed cells denote situation when $\mathrm{D}^{2}\left(\mathrm{R}_{\mathrm{OFE}}\right)<\mathrm{D}^{2}\left(\mathrm{R}_{\mathrm{FIO}}\right)$.

Table 4. Test statistics verifying the hypothesis about expected returns from the benchmarks in considered periods $\mathrm{H}_{0}$ : $\mathrm{E}\left(\mathrm{R}_{\text {benchmark }}\right)=0$

\begin{tabular}{cccccccc}
\hline Periods & A & B1 & B2 & C1 & C2 & D1 & D2 \\
\hline TBSP & $\mathbf{5 . 4 4 9 4}$ & $\mathbf{2 . 8 6 9 4}$ & $\mathbf{3 . 7 7 9 4}$ & $\mathbf{2 . 3 9 6 3}$ & $\mathbf{2 . 8 7 3 1}$ & 1.4714 & 1.6248 \\
WIG & 1.0095 & $\mathbf{1 . 7 0 4 5}$ & -0.0816 & 1.0326 & -0.4643 & 0.4855 & -0.6640 \\
WIBOR3M & $\mathbf{1 3 5 . 2 5 0 5}$ & $\mathbf{2 9 9 . 2 8 5 5}$ & $\mathbf{1 3 2 . 8 2 5 5}$ & $\mathbf{8 1 . 5 0 9 4}$ & $\mathbf{1 0 9 . 2 8 2 0}$ & $\mathbf{1 3 7 . 2 2 2 9}$ & $\mathbf{1 1 6 . 3 4 0 2}$ \\
\hline
\end{tabular}

Note: Bold letters denote rejection of null hypothesis.

Table 5. Cochran-Cox test statistics comparing returns in the pairs of periods

\begin{tabular}{|c|c|c|c|c|c|c|}
\hline \multirow{3}{*}{$\begin{array}{c}\text { Funds type: } \\
\text { Periods: } \\
\text { Allianz }\end{array}$} & \multicolumn{3}{|c|}{ OFE } & \multicolumn{3}{|c|}{ FIO } \\
\hline & B1:B2 & $\mathrm{C} 1: \mathrm{C} 2$ & D1:D2 & B1:B2 & $\mathrm{C} 1: \mathrm{C} 2$ & D1:D2 \\
\hline & 1.0242 & 1.3305 & 0.7179 & 0.5409 & 0.5468 & 0.4707 \\
\hline Aviva & 1.0356 & 1.2945 & 0.8442 & 1.1207 & 1.2931 & 0.8161 \\
\hline NN & 1.0311 & 1.5763 & 0.9342 & 0.9727 & 1.0382 & 0.6518 \\
\hline PEKAO & 1.1848 & 1.3902 & 0.9399 & 1.9662 & 0.6945 & 0.4579 \\
\hline PKO & 1.0890 & 1.4153 & 0.8172 & 0.7175 & 1.3803 & 0.6347 \\
\hline PZU & 1.1246 & 1.1066 & 0.7806 & 0.8989 & 0.9908 & 0.7972 \\
\hline
\end{tabular}

Note: $\mathrm{NN}$ is an abbreviation of Nationale Nederlanden.

Table 5 contains test statistics comparing expected returns generated by both types of funds in two sub-periods: before and after modification of the OFE environment i.e. conditions for their functioning. Null hypothesis cannot be rejected in any case however returns for both pension and stable growth investment funds were always bigger before the change than after, 
and this difference was always bigger for the pension than for mutual funds. In Table 6 comparison of risk is provided and one may notice that for all pension funds risk significantly increased in the periods C2 and D2 i.e. after the introduced by the government changes. For mutual funds we do not observe similar situation since the significant difference of risk between both comparing periods is visible only for Aviva and Nationale Nederlanden in the sub-periods B together with Aviva and PEKAO - in D but in both subperiods the risk before modification of OFE environment is bigger than after.

Table 6. Fisher-Snedecor test statistics comparing variances in the pairs of periods

\begin{tabular}{|c|c|c|c|c|c|c|}
\hline Returns & & OFE & & & $\mathrm{FIO}$ & \\
\hline Periods & B1:B2 & $\mathrm{C} 1: \mathrm{C} 2$ & D1:D2 & B1:B2 & C1:C2 & D1:D2 \\
\hline Allianz & 1.0153 & 3.6597 & 1.5669 & 1.1152 & 1.1070 & 1.0102 \\
\hline Aviva & 1.0448 & 3.9187 & 1.6562 & 1.3252 & 1.0003 & 1.2197 \\
\hline NN & 1.1246 & 2.7625 & 1.6332 & 1.1563 & 1.0788 & 1.1200 \\
\hline PEKAO & 1.0366 & 4.2110 & 1.6346 & 1.0483 & 1.1036 & 1.2319 \\
\hline PKO & 1.0429 & 3.1506 & 1.5867 & 0.7175 & 1.0869 & 1.0805 \\
\hline PZU & 1.1452 & 4.3580 & 1.8796 & 1.0395 & 1.0606 & 1.1538 \\
\hline
\end{tabular}

Note: $\mathrm{NN}$ is an abbreviation of Nationale Nederlanden. Bold letters denote rejection of null hypothesis. Shadowed cells denote situation when $D^{2}\left(R_{\text {before }}\right)<D^{2}\left(R_{\text {after }}\right)$.

Pension funds' portfolios are characterized by smaller risk than stable growth investment funds only in the sub-periods $\mathrm{B}$, the period $\mathrm{C} 1$ for PEKAO and PZU, the period D1 for PZU and in the whole period A for Allianz and PZU. Although the null hypothesis is rejected only for PZU and Allianz in all mentioned periods together with Aviva, Nationale Nederlanden and $\mathrm{PKO}$ in the period $\mathrm{B} 1$. In all sub-periods denoted as $\mathrm{C}$ and D risk of investments made by OFE is significantly bigger than by FIO Allianz, Nationale Nederlanden and PKO, whereas for Aviva and PEKAO this statement is true for C2, D1 and D2 (see Table 3). Comparison of variances in pairs of selected sub-periods (Table 6) shows the significant increase of risk in all pension funds after the new regulations went into effect in 2014, and PEKAO also in 2011 whereas for TBSP and WIBOR only in 2011 (Table 7). This conclusion is not true for stable growth investment funds and the rest of the benchmarks and sub-periods. It is also visible that significant changes in returns took place only in the money market (Table 7). 
Table 7. Cochran-Cox and Fisher-Snedecor test statistics comparing returns $\mathrm{H}_{0}: \mathrm{E}\left(\mathrm{R}_{\text {before }}\right)=\mathrm{E}\left(\mathrm{R}_{\text {after }}\right)$ and variances $\mathrm{H}_{0}: \mathrm{D}^{2}\left(\mathrm{R}_{\text {before }}\right)=\mathrm{D}^{2}\left(\mathrm{R}_{\text {after }}\right)$

\begin{tabular}{ccccccc}
\hline \multicolumn{3}{c}{ Expected returns } & \multicolumn{3}{c}{ Variance } \\
\hline Periods & $\mathrm{B} 1: \mathrm{B} 2$ & $\mathrm{C} 1: \mathrm{C} 2$ & $\mathrm{D} 1: \mathrm{D} 2$ & $\mathrm{~B} 1: \mathrm{B} 2$ & $\mathrm{C} 1: \mathrm{C} 2$ & $\mathrm{D} 1: \mathrm{D} 2$ \\
TBSP & -0.9878 & -0.0836 & 0.0543 & $\mathbf{1 . 3 5 7 6}$ & $\mathbf{1 . 2 6 3 1}$ & $\mathbf{1 . 3 3 7 1}$ \\
WIG & 1.3593 & 1.0740 & 0.8047 & $\mathbf{1 . 4 1 2 9}$ & 1.1331 & $\mathbf{1 . 2 3 6 3}$ \\
WIBOR3M & $\mathbf{- 5 . 7 6 1 0}$ & $\mathbf{3 3 . 2 3 8 8}$ & $\mathbf{3 6 . 1 6 7 5}$ & $\mathbf{5 . 6 3 7 4}$ & $\mathbf{5 . 5 4 8 0}$ & $\mathbf{1 . 6 1 2 9}$ \\
\hline
\end{tabular}

Note: Shadowed cells denote situation when $\mathrm{D}^{2}\left(\mathrm{R}_{\text {before }}\right)<\mathrm{D}^{2}\left(\mathrm{R}_{\text {after }}\right)$. Bold letters denote rejection of $\mathrm{H}_{0}$.

\section{Single Index and Capital Assets Pricing Models}

The models are estimated for each period of analysis using WIG as the market index and two variants of risk free instruments i.e. TBSP and WIBOR in the capital assets pricing models (CAPM). Therefore, there are 21 models for each fund, which parameters will be compared. Beta coefficients in all models estimated for the pension funds are significantly positive (except the models estimated for OFE PZU in the periods: A, B1, C2, D1, and D2). Value of parameter estimates increase from 0.2 in B1, by 0.3 in B2 and C1, 0.4 in D2 to 0.6 in C2 and D2. Parameter estimates of beta and determination coefficients in the single index models and the capital assets pricing models with WIBOR as the risk free instrument are almost of the same values whereas using TBSP as the risk free instrument gives slightly different values of beta for all models estimated for the pension funds (the example in Table 8). Similar conclusions may be drawn for the stable growth investment funds (see Table 9) however values of the determination coefficients are different in models describing both types of funds.

Table 8. Estimates and determination coefficients of different pension funds models estimated for in the whole period

\begin{tabular}{|c|c|c|c|c|c|c|}
\hline & Allianz & Aviva & NN & PEKAO & PKO & PZU \\
\hline \multicolumn{7}{|c|}{ Beta coefficient } \\
\hline Sharpe & 0.2976 & 0.3003 & 0.3119 & 0.3044 & 0.2897 & 0.0132 \\
\hline CAPM WIBOR & 0.2976 & 0.3003 & 0.3119 & 0.3044 & 0.2897 & 0.0132 \\
\hline CAPM TBSP & 0.2762 & 0.2785 & 0.2892 & 0.2827 & 0.2682 & -0.0027 \\
\hline \multicolumn{7}{|c|}{ Determination coefficient } \\
\hline Sharpe & 0.5567 & 0.5538 & 0.5531 & 0.5189 & 0.5434 & 0.0009 \\
\hline CAPM WIBOR & 0.5567 & 0.5539 & 0.5531 & 0.5190 & 0.5435 & 0.0009 \\
\hline CAPM TBSP & 0.5182 & 0.5168 & 0.5201 & 0.4802 & 0.5029 & 0.0000 \\
\hline
\end{tabular}

Note: Bold letters denote statistically significant parameters i.e. $\mathrm{H}_{0}: \beta=0$; $\mathrm{NN}$ as in Table 3 . 
Table 9. Parameter estimates and determination coefficients of different models estimated for mutual funds in the whole period

\begin{tabular}{|c|c|c|c|c|c|c|}
\hline & Allianz & Aviva & NN & PEKAO & PKO & PZU \\
\hline \multicolumn{7}{|c|}{ Beta coefficient } \\
\hline Sharpe & 0.3221 & 0.3379 & 0.3396 & 0.3396 & 0.2638 & 0.6389 \\
\hline CAPM WIBOR & 0.3221 & 0.3379 & 0.3396 & 0.3396 & 0.2638 & 0.6389 \\
\hline CAPM TBSP & 0.2977 & 0.3155 & 0.3165 & 0.3165 & 0.2409 & 0.6262 \\
\hline \multicolumn{7}{|c|}{ Determination coefficient } \\
\hline Sharpe & 0.5406 & 0.8632 & 0.9029 & 0.9029 & 0.8041 & 0.9406 \\
\hline CAPM WIBOR & 0.5406 & 0.8632 & 0.9029 & 0.9029 & 0.8041 & 0.9406 \\
\hline CAPM TBSP & 0.5115 & 0.8644 & 0.9435 & 0.9435 & 0.8103 & 0.9400 \\
\hline
\end{tabular}

Note: Bold letters denote statistically significant parameters i.e. $\mathrm{H}_{0}: \beta=0$; $\mathrm{NN}$ is an abbreviation of Nationale Nederlanden.

In the next step we compare betas from the models estimated before and after the changes of the pension funds' situation, introduced by the government ${ }^{5}$. It is visible that for all models estimated for the pension funds the risk significantly increased in the second considered periods (Table 10). Comparing beta coefficients estimated for the mutual funds the same results are obtained only for FIO Allianz whereas for other stable growth investment funds the results of the hypothesis verification are different (Table 11). For Aviva, PEKAO and PZU the risk significantly decreased in the period D2 in comparison to the period D1, also for the first considered pair of sub-periods FIO Aviva are characterized by the smaller risk after the modification of the system than before. Compering a pair of sub-periods $\mathrm{C} 1$ and $\mathrm{C} 2$, we notice that there is only one case (PEKAO for the CAPM model with TBSP) when risk significantly decreased in the second compared period.

Table 10. Student test statistics comparing betas estimated for the pension funds in the pairs of periods $\mathrm{H}_{0}: \beta_{\text {before }}=\beta_{\text {after }}$

\begin{tabular}{ccccccc}
\hline & \multicolumn{2}{c}{ B1:B2 } & \multicolumn{2}{c}{ C1:C2 } & \multicolumn{2}{c}{ D1:D2 } \\
\hline Models & Sharpe & CAPM TBSP & Sharpe & CAPM TBSP & Sharpe & CAPM TBSP \\
\hline Allianz & -4.70 & -7.51 & -33.46 & -31.83 & -12.89 & -12.54 \\
Aviva & -3.80 & -6.71 & -36.32 & -36.51 & -14.51 & -14.62 \\
NN & -2.95 & -5.81 & -34.50 & -34.90 & -14.06 & -14.55 \\
PEKAO & -5.35 & -8.09 & -37.60 & -36.23 & -14.08 & -13.85 \\
PKO & -4.45 & -7.44 & -35.79 & -34.35 & -13.31 & -13.17 \\
PZU & -0.92 & -3.16 & 2.02 & 3.22 & -1.77 & -1.00 \\
\hline
\end{tabular}

Note: Bold letters denote rejection of null hypothesis.

\footnotetext{
${ }^{5}$ In comparison parameter estimates from the CAPM using WIBOR as risk free instrument were omitted because they were of the same values as in the Sharp models.
} 
Table 11. Student test statistics comparing betas estimated for the mutual funds in the pairs of periods $\mathrm{H}_{0}: \beta_{\text {before }}=\beta_{\text {after }}$

\begin{tabular}{ccccccc}
\hline & \multicolumn{2}{c}{ B1:B2 } & \multicolumn{2}{c}{ C1:C2 } & \multicolumn{2}{c}{ D1:D2 } \\
\hline Models & Sharpe & CAPM TBSP & Sharpe & CAPM TBSP & Sharpe & CAPM TBSP \\
\hline Allianz & -9.9973 & -11.5962 & -9.8910 & -8.7862 & -6.1679 & -4.8829 \\
Aviva & 13.9977 & 13.0450 & -4.8720 & -6.2323 & $\mathbf{2 . 0 1 4 7}$ & 3.3168 \\
NN & -0.3876 & -0.3003 & -2.8112 & -1.7663 & -0.8466 & -0.8954 \\
PEKAO & $-\mathbf{8 . 0 1 9 6}$ & -8.9997 & 0.6125 & $\mathbf{2 . 2 5 9 1}$ & 4.3964 & 4.3668 \\
PKO & -11.0755 & -11.7400 & -14.4898 & 0.6200 & -1.4324 & -1.3214 \\
PZU & $-\mathbf{1 8 . 4 0 4 5}$ & $-\mathbf{- 2 0 . 9 3 6 8}$ & $-\mathbf{8 9 . 8 6 7 8}$ & $-\mathbf{8 5 . 1 7 3 6}$ & $\mathbf{3 . 3 1 4 4}$ & $\mathbf{3 . 9 9 4 7}$ \\
\hline
\end{tabular}

Note: Bold letters denote rejection of null hypothesis.

We also compare betas from the models estimated for the pension and mutual funds (Table 12), and it is visible that in the periods denoted as A, B1, B2 and $\mathrm{C} 1$, all pension funds except $\mathrm{PKO}$ in $\mathrm{A}$ and Allianz in $\mathrm{C} 1$ are characterized by bigger risk than mutual funds since betas are significantly bigger for OFE than for FIO in the majority of cases. Whereas in the sub-periods C2, D1 and D2 the situation is the opposite except PZU.

Table 12. Student test statistics comparing betas estimated for the pension and mutual funds in all periods $\mathrm{H}_{0}: \beta_{\mathrm{OFE}}=\beta_{\mathrm{FIO}}$

\begin{tabular}{crrrrrrr}
\hline \multicolumn{1}{c}{ A } & \multicolumn{1}{c}{ B1 } & \multicolumn{2}{c}{ B2 } & \multicolumn{1}{c}{ C1 } & \multicolumn{1}{c}{ C2 } & \multicolumn{1}{c}{ D1 } & \multicolumn{1}{c}{ D2 } \\
\hline Allianz & -3.5144 & -3.0930 & -16.4158 & 1.9904 & 51.7384 & 16.6141 & 41.4479 \\
AVIVA & -11.9270 & -34.7256 & -10.2976 & -0.3780 & 47.4091 & 9.2631 & 43.6863 \\
PKO & 8.3548 & -5.9057 & -12.4800 & -0.5507 & 57.8852 & 18.6757 & 47.5616 \\
NN & -10.6034 & -28.0973 & -17.7427 & -5.2973 & 57.7356 & 11.6558 & 47.2607 \\
PEKAO & -21.4350 & -31.5047 & -23.6178 & -13.0494 & 53.8435 & 5.1663 & 47.3234 \\
PZU & -166.4176 & -127.2500 & -112.5233 & -88.3038 & -80.0261 & -79.1466 & -63.7252 \\
\hline \multicolumn{7}{c}{ CAPM TBSP } \\
\hline Allianz & -3.1584 & -2.8330 & -16.8911 & 3.0855 & 75.3923 & 20.0192 & 64.5078 \\
AVIVA & -13.8325 & -37.1812 & -12.5294 & 1.1703 & 61.7681 & 15.9266 & 57.5696 \\
PKO & 10.1111 & -6.7755 & -17.3235 & 0.8600 & 57.1452 & 25.1786 & 45.0649 \\
NN & -15.0291 & -36.9608 & -30.1785 & -7.3074 & 78.8268 & 23.2502 & 66.6716 \\
PEKAO & -25.9866 & -33.3984 & -24.1046 & -13.7403 & 33.1803 & 0.5113 & 28.3302 \\
PZU & -169.5121 & -134.2389 & -115.0464 & -90.6541 & -81.3673 & -80.3593 & -64.7672 \\
\hline
\end{tabular}

Note: Bold letters denote rejection of null hypothesis. NN is an abbreviation of Nationale Nederlanden.

\section{Investment Efficiency Evaluation}

The last stage of our investigation consists in comparison of classical efficiency measures, which are evaluated for different portfolios and samples. It is worth reminding that applying so called reward-to-variability (Sharpe) and reward-to-volatility (Treynor) ratios, it is necessary to define 
the risk free instrument and the market index. Since in our previous analysis we use two risk free instruments WIBOR and TBSP together with WIG, which represents the capital market, the same instruments are used to evaluate the performance of considered pension and mutual funds. However, to evaluate Treynor ratio we use betas from both i.e. single index and capital assets pricing models. In other words, for each pension or mutual fund we calculate two Sharpe's and Jensen ratios, together with four Treynor's measures. Tables 13 and 14 contain the average values of these efficiency measures.

Table 13. Average values of the efficiency measures evaluated for pension funds

\begin{tabular}{|c|c|c|c|c|c|c|c|c|}
\hline Period & Measure & Allianz & Aviva & PKO & $\mathrm{NN}$ & PEKAO & $\overline{P Z U}$ & $\overline{W I G}$ \\
\hline & Sharpe & 0.0100 & 0.0060 & 0.0125 & 0.0079 & 0.0025 & 0.0075 & 0.0096 \\
\hline \multirow[t]{2}{*}{ A } & Treynor & 0.0002 & 0.0001 & 0.0002 & 0.0001 & 0.0000 & 0.0057 & 0.0001 \\
\hline & Jensen & 0.0000 & 0.0000 & 0.0000 & 0.0000 & 0.0000 & 0.0000 & \\
\hline & Sharpe & 0.0716 & 0.0681 & 0.0768 & 0.0700 & 0.0731 & 0.0670 & 0.0584 \\
\hline \multirow[t]{3}{*}{ B1 } & Treynor & 0.0013 & 0.0012 & 0.0014 & 0.0010 & 0.0013 & 0.0114 & 0.0008 \\
\hline & Jensen & 0.0001 & 0.0001 & 0.0001 & 0.0001 & 0.0001 & 0.0003 & \\
\hline & Sharpe & -0.0006 & -0.0042 & 0.0007 & -0.0004 & -0.0095 & -0.0087 & -0.0212 \\
\hline \multirow[t]{3}{*}{ B2 } & Treynor & 0.0000 & -0.0001 & 0.0000 & 0.0000 & -0.0002 & -0.0013 & -0.0002 \\
\hline & Jensen & 0.0001 & 0.0000 & 0.0001 & 0.0001 & 0.0000 & 0.0000 & \\
\hline & Sharpe & 0.0625 & 0.0535 & 0.0816 & 0.0758 & 0.0540 & 0.0519 & 0.0281 \\
\hline \multirow[t]{3}{*}{ C1 } & Treynor & 0.0007 & 0.0006 & 0.0011 & 0.0010 & 0.0007 & 0.0089 & 0.0003 \\
\hline & Jensen & 0.0001 & 0.0001 & 0.0001 & 0.0001 & 0.0001 & 0.0002 & \\
\hline & Sharpe & -0.0319 & -0.0354 & -0.0280 & -0.0382 & -0.0405 & -0.0278 & -0.0391 \\
\hline \multirow[t]{3}{*}{$\mathrm{C} 2$} & Treynor & -0.0003 & -0.0004 & -0.0003 & -0.0004 & -0.0004 & 0.0109 & -0.0003 \\
\hline & Jensen & 0.0000 & 0.0000 & 0.0000 & 0.0000 & -0.0001 & -0.0002 & \\
\hline & Sharpe & 0.0127 & 0.0142 & 0.0232 & -0.0024 & 0.0149 & 0.0187 & 0.0075 \\
\hline \multirow[t]{3}{*}{ D1 } & Treynor & 0.0002 & 0.0003 & 0.0003 & 0.0000 & 0.0002 & 0.0052 & 0.0001 \\
\hline & Jensen & 0.0000 & 0.0000 & 0.0001 & 0.0001 & 0.0000 & 0.0001 & \\
\hline & Sharpe & -0.0334 & -0.0291 & -0.0313 & -0.0418 & -0.0461 & -0.0326 & -0.0449 \\
\hline \multirow[t]{2}{*}{$\mathrm{D} 2$} & Treynor & -0.0003 & -0.0004 & -0.0003 & -0.0004 & -0.0005 & -0.0072 & -0.0004 \\
\hline & Jensen & 0.0000 & 0.0000 & 0.0000 & 0.0000 & 0.0000 & -0.0002 & \\
\hline
\end{tabular}

Note: Bold letters denote ratios evaluated for pension funds which are bigger than the ones calculated for WIG. NN is an abbreviation of Nationale Nederlanden.

It is visible that in the majority of cases (76\%) pension funds performed better than capital market if the efficiency is measured by the averages of Treynor and Sharpe ratios. Only Nationale Nederlanden OFE did not perform better in the periods A, C2 (only Treynor measure), and D2. In fact, in C2 and D2 sub-periods also other pension funds show lower efficiency. Applying Jensen alpha, it is visible that in majority of cases values are nonnegative. Although positive and statistically significant values of the parameter alpha in the CAPM (when WIBOR is the risk free instrument) are observed 
only for OFE Allianz, Nationale Nederlanden and PKO in the period C1, together with OFE PZU in the period B1 (see Table 15).

It is visible that in the majority of cases mutual funds performed worse than capital market. There are only 12 cases among 84 average of Treynor or Sharpe measure values (14\%) when stable growth investment fund is more efficient than capital market represented by WIG. The mutual funds which were better managed are FIO Aviva, PKO and PZU. Also Jensen ratio is rarely positive for mutual funds and if the constant in the capital assets pricing models, estimated for investment funds, is statistically significant it is always negative for FIO Allianz and both risk free instruments in the whole period of analysis, FIO Nationale Nederlanden, PEKAO, PKO and PZU for TBSP in the whole period of analysis and in the sub-period B1 for Nationale Nedrelanden and TBSP, together with PEKAO regardless the risk free instrument (see Table 15).

Table 14. Average values of the efficiency measures evaluated for mutual funds

\begin{tabular}{ccrrrrrrr}
\hline Period & Measure & Allianz & Aviva & PKO & NN & PEKAO & PZU & WIG \\
\hline \multirow{4}{*}{ A } & Sharpe & -0.0298 & $\mathbf{0 . 0 0 9 7}$ & 0.0034 & 0.0023 & -0.0282 & -0.0014 & 0.0096 \\
& Treynor & -0.0005 & 0.0001 & 0.0000 & 0.0000 & -0.0003 & 0.0000 & 0.0001 \\
& Jensen & -0.0002 & 0.0000 & 0.0000 & 0.0000 & -0.0002 & -0.0001 & \\
\hline \multirow{3}{*}{ B1 } & Sharpe & -0.0021 & 0.0522 & 0.0368 & 0.0442 & -0.0743 & 0.0427 & 0.0584 \\
& Treynor & -0.0001 & 0.0008 & 0.0005 & 0.0005 & -0.0010 & 0.0006 & 0.0008 \\
& Jensen & -0.0002 & 0.0000 & 0.0000 & 0.0000 & -0.0001 & -0.0001 & \\
\hline \multirow{3}{*}{ B2 } & Sharpe & -0.0448 & -0.0195 & -0.0183 & -0.0216 & -0.0848 & -0.0196 & -0.0212 \\
& Treynor & -0.0006 & -0.0003 & -0.0002 & -0.0003 & -0.0010 & -0.0099 & -0.0002 \\
& Jensen & -0.0001 & 0.0000 & 0.0000 & 0.0000 & -0.0003 & 0.0000 & \\
\hline \multirow{2}{*}{ C1 } & Sharpe & -0.0534 & $\mathbf{0 . 0 3 1 1}$ & 0.0271 & 0.0264 & -0.0144 & $\mathbf{0 . 0 4 2 0}$ & 0.0281 \\
& Treynor & -0.0006 & 0.0003 & 0.0003 & 0.0003 & -0.0001 & 0.0004 & 0.0003 \\
& Jensen & -0.0002 & 0.0000 & 0.0001 & 0.0000 & -0.0002 & 0.0001 & \\
\hline \multirow{2}{*}{ C2 } & Sharpe & -0.0772 & -0.0456 & -0.0296 & -0.0349 & -0.0573 & -0.0487 & -0.0391 \\
& Treynor & -0.0007 & -0.0005 & -0.0003 & -0.0003 & -0.0005 & -0.0004 & -0.0003 \\
& Jensen & -0.0001 & 0.0000 & 0.0000 & 0.0000 & -0.0001 & -0.0001 & \\
\hline \multirow{2}{*}{ D1 } & Sharpe & -0.0532 & $\mathbf{0 . 0 1 4 3}$ & -0.0187 & -0.0033 & -0.0256 & 0.0072 & 0.0075 \\
& Treynor & -0.0006 & $\mathbf{0 . 0 0 0 2}$ & -0.0002 & 0.0000 & -0.0003 & 0.0001 & 0.0001 \\
& Jensen & -0.0002 & 0.0000 & 0.0000 & 0.0000 & -0.0001 & 0.0000 & \\
\hline \multirow{2}{*}{ D2 } & Sharpe & -0.0802 & -0.0401 & -0.0330 & -0.0474 & -0.0626 & -0.0498 & -0.0449 \\
& Treynor & -0.0008 & -0.0004 & -0.0003 & -0.0004 & -0.0006 & -0.0004 & -0.0004 \\
& Jensen & -0.0001 & 0.0000 & 0.0000 & 0.0000 & -0.0001 & 0.0000 & \\
\hline
\end{tabular}

Note: Bold letters denote ratios evaluated for mutual funds which are bigger than the ones calculated for WIG. NN is an abbreviation of Nationale Nederlanden. 


\section{Conclusion}

Investigation is provided for the selected pension funds and stable growth open investment funds which have been operating in frame of the six Investment and Pension Funds Companies. During the period of analysis, i.e. the years 2009-2015, the essential changes of the pension funds functioning were introduced therefore, research is conducted for three distinguished pairs of sub-periods. These pairs: B (B1 and B2), C (C1 and C2), and D (D1 and D2) are characterized by similar numbers of observations to make the comparison of the considered pension and mutual funds' performance possible.

Provided analysis let us conclude that changes in the operation of pension funds influence not only the pension funds market but the whole capital market in Poland. The latter seems not to recover after the financial crisis 2007-2009 (see Table 4) and its performance is worse in all periods after the modifications were introduced than before i.e. Sharpe and Treynor ratios are positive in the sub-periods B1, C1 and D1 and negative for B2, C2 and D2 (Tables 13-14). Also pension funds investment efficiency is worse after the changes went into effect, especially they cause the significant increase of the pension funds' investment portfolios risk (see Tables 6 and 10).

Table 15. Parameter estimates of constant in CAPM for which $\mathrm{H}_{0}: \alpha=0$ is rejected

\begin{tabular}{|c|c|c|c|c|c|c|}
\hline \multirow{2}{*}{ Fund } & \multicolumn{3}{|c|}{ OFE } & \multicolumn{3}{|c|}{$\mathrm{FIO}$} \\
\hline & parameter & period & instrument & parameter & period & instrument \\
\hline \multirow{2}{*}{ Allianz } & \multirow{2}{*}{0.0002} & \multirow{2}{*}{ C1 } & \multirow{2}{*}{ WIBOR } & -0.0001 & $\bar{A}$ & WIBOR \\
\hline & & & & -0.0002 & A & TBSP \\
\hline \multirow{2}{*}{$\begin{array}{c}\text { Nationale } \\
\text { Nederlanden }\end{array}$} & \multirow{2}{*}{0.0002} & \multirow{2}{*}{ C1 } & \multirow{2}{*}{ WIBOR } & -0.0001 & $\bar{A}$ & TBSP \\
\hline & & & & -0.0001 & B1 & TBSP \\
\hline \multirow{3}{*}{ PEKAO } & & & & -0.0001 & A & TBSP \\
\hline & & & & -0.0003 & B1 & WIBOR \\
\hline & & & & -0.0004 & B1 & TBSP \\
\hline PKO & 0.0002 & C1 & WIBOR & -0.0001 & $A$ & TBSP \\
\hline PZU & 0.0003 & B1 & WIBOR & -0.0001 & $A$ & TBSP \\
\hline
\end{tabular}

Comparison of the pension and stable growth investment funds' performance shows that the former were in analyzed periods more effective than the latter (compare Tables 13 and 14). Considered changes of the pension system have not effected mutual funds' investment policy directly however the general situation of the Polish capital market influences situation of FIOs. 


\section{References}

Analizy (2013), Wspólny raport Analiz Online oraz Izby Zarządzających funduszami i Aktywami z dnia 8 marca 2013, Analizy online.

Białek J., Konstrukcja miar efektywności Otwartych Funduszy Emerytalnych, Wydawnictwo Uniwersytetu Łódzkiego, Łódź, 2009.

Chybalski, F. (2006), Miary oceny działalności inwestycyjnej OFE, Wiadomości Statystyczne, $10,22-35$.

Chybalski, F. (2009) (red.), Otwarte fundusze emerytalne w Polsce. Analiza działalności inwestycyjnej, finansów oraz decyzji członków, C.H. Beck, Warszawa.

Dybał, M. (2008), Efektywność inwestycyjna funduszy emerytalnych, CeDeWu.pl, Warszawa.

Karpio, A., Żebrowska-Suchodolska D. (2010), Stabilność strategii inwestycyjnych FIO akcji w latach 2003-2009, Uniwersytet Szczeciński, Zeszyty Naukowe Nr 612 „Finanse, Rynki finansowe, ubezpieczenia", 28, 409-418.

Karpio, A., Żebrowska-Suchodolska, D. (2011), Stability of strategies of Polish open-end investment funds investing in global markets during the financial crisis, Acta Scientiarum Polonorum, Oeconomia, Wydawnictwo SGGW w Warszawie, 10(3), $51-59$.

Karpio, A., Żebrowska-Suchodolska, D. (2014), Ocena zarządzania portfelami otwartych funduszy inwestycyjnych z wykorzystaniem różnych miar efektywności inwestycyjnej, Metody matematyczne i informatyczne $w$ finansach $i$ ubezpieczeniach, Metody 2012, 207, 136-147.

Karpio A., Żebrowska-Suchodolska D. (2014a), The Influence of Pension Funds on the Polish Capital Market, Metody Ilościowe w Badaniach Ekonomicznych, Wydawnictwo SGGW, 15(1), 50-57.

Karpio, A., Żebrowska-Suchodolska, D. (2016), Polish open-end pension funds performance and its persistency, Acta Scientiarum Polonorum, Oeconomia, Wydawnictwo SGGW, $15(1), 15-25$.

Kompa, K., Wiśniewski T. (2015), Dywersyfikacja portfeli otwartych funduszy emerytalnych - kaprys czy konieczność? Finanse, rynki finansowe, ubezpieczenia. Zeszyty Naukowe Uniwersytetu Szczecińskiego, 75, 245-255,

DOI: http://dx.doi.org/10.18276/frfu.2015.75-20.

Kompa, K., Witkowska, D. (2014), Pension Funds in Poland: Efficiency Analysis for Years 1999-2013, Dynamic Econometric Models, 14, 105-124, DOI: http://dx.doi.org/10.12775/DEM.2014.006.

Kompa, K., Witkowska, D. (2015), Pension system in Poland: Performance of Pension Funds, Estudios De Economia Aplicada, 33(3), 965-984.

Kompa, K., Witkowska, D. (2015), Transformation of Polish Pension System: Government Manipulations Instead of Improvement, in: Montero Lorenzo, J.M., Jiménez, J.M., Salido, R.M. (eds.) Sostenibilidad y Suficiencia de los Sistemas de Pensiones (Sustainability and Sufficiency of Pensions Systems), Anales de Economía Aplicada (XXIX), 836-846, Cuenca, ASEPELT, http://www.asepelt.org/modules.php?name=Content\&pa $=$ showpage $\&$ pid $=67$.

Kompa, K., Witkowska, D. (2016), Efficiency of private pension funds in Poland, AESTIMATIO, the IEB International Journal of Finance, 12, 48-65, DOI: http://dx.doi.org/10.5605/IEB.12.3.

Marcinkiewicz, E. (2009), Analiza stóp zwrotu OFE w: Chybalski F. (red.), Otwarte fundusze emerytalne $w$ Polsce. Analiza działalności inwestycyjnej, finansów oraz decyzji członków, C. H. Beck, Warszawa, 135-148.

Dynamic Econometric Models 16 (2016) 117-131 
Mikulec, A. (2004), Ocena efektywności inwestowania Otwartych Funduszy Emerytalnych, Wiadomości Statystyczne, 9, 26-39.

Ostrowska, E. (2003), Efektywność funduszy inwestycyjnych na polskim rynku finansowym wskaźniki Sharpe'a, Treynora i Jensena, [w] Prace naukowe Akademii Ekonomicznej we Wrocławiu, Inwestycje finansowe i ubezpieczenia - tendencje światowe a polski rynek, red. nauk. Jajuga, K., Ronka-Chmielowiec, W., Wydawnictwo Akademii Ekonomicznej we Wrocławiu, Wrocław.

Ostrowska, K. (2013), Jakie opłaty w OFE, Moja Emerytura, serwis dziennika Rzeczpospolita, www.rp.pl/artykul/975301-Jakie-oplaty-w-OFE-.html\#ap-1.

Perez, K. (2012a), Efektywność funduszy inwestycyjnych. Difin, Warszawa.

Perez, K. (2012b), Persystencja stóp zwrotu polskich funduszy inwestycyjnych, Finanse, Komitet Nauk o Finansach PAN, 1(5), 81-113.

Podstawka, M. (2005), Podstawy finansów teoria i praktyka, Wyd. SGGW, Warszawa.

Tarczyński, W., Witkowska, D. and Kompa, K. (2013), Współczynnik beta. Teoria i praktyka, Pielaszek Research, Warszawa, https://books.google.pl/books/about/WSP\%C3\%93\%C5\%81czynnik_beta_teoria_i_pr aktyka.html?id=ZnWZAgAAQBAJ\&redir_esc $=y$.

Witkowska, D. (2009), Efektywność wybranych funduszy akcyjnych w latach 2005-2007, Ekonomika i Organizacja Gospodarki Żywnościowej, Zeszyty Naukowe Szkoły Głównej Gospodarstwa Wiejskiego w Warszawie, 74, 39-61.

Witkowska D., Kompa K., Grabska M. (2009), Badanie informacyjnej efektywności rynku w formie silnej na przykładzie wybranych funduszy inwestycyjnych, Metody ilościowe w Badaniach Ekonomicznych, Warszawa, 10, 265-286.

Wojciechowski, W. (2011), Reforma emerytalna: fakty i liczby zamiast błędów i mitów, Liberte $\mathrm{Nr} 22,14.01 .2011$, http://liberte.pl/reforma-emerytalna-fakty-i-liczby-zamiastbledow-i-mitow.

Zamojska, A. (2012), Efektywność funduszy inwestycyjnych w Polsce. Studium teoretycznoempiryczne, C. H. Beck, Warszawa.

\section{Efektywność funduszy emerytalnych i otwartych funduszy inwestycyjnych stabilnego wzrostu w czasie zmian w polskim systemie emerytalnym}

$\mathrm{Z}$ a r y s t r és c i. Warunki funkcjonowania funduszy emerytalnych (OFE) zostały zasadniczo zmienione w latach 2011-2014. Celem artykułu jest badanie, czy zmiany te wpływają na efektywność funduszy emerytalnych oraz porównanie efektywności tych funduszy ze efektywnością otwartych funduszy inwestycyjnych stabilnego wzrostu (FIO). Analizie poddano wybrane fundusze w latach 2009-2015. Stwierdzono, że w badanym okresie OFE osiaggały lepsze wyniki niż porównywane FIO. Zarazem modyfikacje zasad działania OFE spowodowały wzrost ryzyka i zmniejszenie efektywności inwestycyjnej portfeli tych funduszy.

S łow a kluczowe: fundusze emerytalne, otwarte fundusze inwestycyjne stabilnego wzrostu, efektywność inwestycyjna, model Sharpe'a, CAPM, wskaźniki Sharpe'a, Treynora i Jensena. 
